\title{
The Role of Green Entrepreneurship in Understanding Indonesia Economy Development Sustainability among Young Adults
}

\author{
KARTIKA NURINGSIH ${ }^{1}$, NURYASMAN MN² \\ ${ }^{1}$ Faculty of Economics \& Business, UNIVERSITAS TARUMANAGARA, INDONESIA. E-mail: kartikan@fe.untar.ac.id \\ ${ }^{2}$ Faculty of Economics \& Business, UNIVERSITAS TARUMANAGARA, INDONESIA. E-mail: \\ nuryasman@fe.untar.ac.id:
}

\begin{abstract}
Along with efforts to achieve sustainable development goals (SDGs), the purpose of this study investigates the relationship between green value, education support, green entrepreneurship, and sustainable development with involving respondents at Kulon Progo County in Daerah Istimewa Yogyakarta province. The study employs samples of as many as 130 students of higher education institutions to collect data through questionnaires. This study uses Smart-Pls for data processing with the following results: first, green entrepreneurship has a significant effect at the $5 \%$ level on sustainable development. Second, green values and education support have no significant effect on sustainable development. Third, green values and education support have a significant effect on the $5 \%$ level of green entrepreneurship. The findings in this study suggest that green values and education support are the starting point in forming a positive perception of green entrepreneurship. Through this approach, the younger generation will easily understand sustainable development. It is concluded that the entrepreneurship learning system must be in line with the aspects of sustainable development so that young adults will be more understanding of the benefits of implementing eco-friendly business activities in supporting the achievement of SDGs in 2030.
\end{abstract}

Keywords: Education Support; Green Entrepreneurship; Green Value; Sustainable Development.

JEL Classification: F64, L26, Q01

Received: June 4, 2021

Accepted: September 15, 2021 


\title{
El Papel de la Iniciativa Empresarial Ecológica en la Comprensión de la Sostenibilidad del Desarrollo de la Economía Indonesia entre los Jóvenes Adultos
}

\author{
KARTIKA NURINGSIH ${ }^{1}$, NURYASMAN MN² \\ ${ }^{1}$ Faculty of Economics \& Business, UNIVERSITAS TARUMANAGARA, INDONESIA. E-mail: kartikan@fe.untar.ac.id \\ ${ }^{2}$ Faculty of Economics \& Business, UNIVERSITAS TARUMANAGARA, INDONESIA. \\ E-mail: nuryasman@fe.untar.ac.id:
}

\begin{abstract}
RESUMEN
Junto con los esfuerzos para lograr los objetivos de desarrollo sostenible (ODS), el propósito de este estudio investiga la relación entre el valor verde, el apoyo a la educación, el espíritu empresarial verde y el desarrollo sostenible con la participación de los encuestados en el condado de Kulon Progo en la provincia de Daerah Istimewa Yogyakarta. El estudio emplea muestras de hasta 130 estudiantes de instituciones de educación superior para recoger datos a través de cuestionarios. Este estudio utiliza Smart-PIs para el procesamiento de datos con los siguientes resultados: primero, el espíritu empresarial verde tiene un efecto significativo al nivel del 5\% sobre el desarrollo sostenible. En segundo lugar, los valores ecológicos y el apoyo a la educación no tienen un efecto significativo sobre el desarrollo sostenible. En tercer lugar, los valores ecológicos y el apoyo a la educación tienen un efecto significativo al nivel del 5\% sobre el emprendimiento ecológico. Los resultados de este estudio sugieren que los valores ecológicos y el apoyo a la educación son el punto de partida para formar una percepción positiva del espíritu empresarial ecológico. Gracias a este enfoque, la generación más joven comprenderá fácilmente el desarrollo sostenible. Se concluye que el sistema de aprendizaje del espíritu empresarial debe estar en consonancia con los aspectos del desarrollo sostenible para que los jóvenes adultos comprendan mejor los beneficios de la realización de actividades empresariales ecológicas para apoyar la consecución de los ODS en 2030.
\end{abstract}

Palabras clave: Apoyo a la educación; Emprendimiento verde; Valor verde; Desarrollo sostenible.

Clasificación JEL: F64, L26, Q01

Recibido: 04 de Junio de 2021

Aceptado: 15 de Septiembre de 2021 


\section{Introduction}

The results of business activities contribute to improving the welfare of the community. However, the impact of these business activities can disrupt environmental sustainability and socio-cultural changes. Natural disasters such as floods, landslides, forest fires, or drought are one of the effects of uncontrolled exploitation of natural resources, so it is necessary to balance economic orientation by saving the nature. For this reason, the current economic development system needs the mechanism to balance the impact of the business practices to maintain sustainability. The United Nations Environmental Program (UNEP, 2011) has fostered the reducing environmental risks and ecological scarcities through a green economy. Its goal improves human well-being and social equity; thus, the global community requires a harmonizing program that meets the welfare of the current and future generations. For achieving this goal, the business practices must align with the values of sustainability so can realize social welfare and preserve the quality of natural resources.

Therefore, along with the Covid-19 pandemic, it can encourage social solidarity so that people become more sensitive to environmental changes. It has been proven since it broke out in Wuhan, China at the end of 2019 until the pandemic still has not ended today. In line with the statement of the World Wide Foundation, explains this global tragedy through a "pathway of epidemics" caused by natural exploitation such as deforestation, wild species collecting, or animal trafficking (WWF International, 2020). Preventing deforestation will withstand the effects of climate change, maintain biodiversity and slow down the migration of animals to new habitats. Meanwhile, animal trafficking tends to bring endangered species closer to human habitats, so there is a risk of disease transmission to humans. This migration changes the transmission of disease from animal to animal to animal to human and finally human to human. Even changes in the ecosystem can trigger a zoonotic effect. Learning from the outbreak, it must have been insight to foster the conservation and nature maintenance awareness among people including in creating new ventures.

In aligning with the issues of sustainability, entrepreneurs must respect social welfare, environmental sustainability, and cultural social changes. This is not easily appreciated by the public, especially in the business sector. As a protection for environmental sustainability for future generations, the role of the education sector is needed to transform knowledge and learning models that are in line with sustainable development. The learning method is expected to combine strengthening skills, preparing knowledge of work, and understanding sustainability issues so that goal of education is connected with the goals of sustainable development and a green economy. Hence, the entrepreneurial learning system must work in synergy with the triple bottom line to encourage the introduction of green business among young adults. Nowadays, learning entrepreneurship is not a new thing for students, it is even a part of the curriculum so that the majority of students accept entrepreneurship learning. Therefore, it is necessary to broaden the design thinking about sustainable development such as achieving profit, making environmental solutions, and moving green ethics in entrepreneurial education. The moving of green entrepreneurship fosters the awareness of natural preservation and social equality as the basis of regional development. This mechanism must be understood among students. Under the outbreak situation, this study observes generally how young adults can perceive the green entrepreneurial model as a solution for sustainability problems in the current and future.

For these reasons, this study investigates this moment among students at Kulon Progo district. As part of the province of Daerah Istimewa Yogyakarta (DIY), awareness of education is felt in people's lives. The Central Bureau of Statistics in 2018 noted that people in Yogyakarta have the highest life expectancy in Indonesia. This describes a good social life condition that must be maintained through sustainability-oriented regulations. The majority of the population lives in rural areas and depends on agriculture so that the development of this sector is important for the welfare of the community. The efforts to realize sustainable agricultural development must be followed by an understanding of environmental sustainability (Sargani, Zhou, Raza, \& Wei, 2020) so that the commercialization of agricultural products is carried out through a green entrepreneurship approach. Along with the 
development of infrastructure, higher education institutions are opening new campuses so that they further support the literate atmosphere of the community. This development is not impossible to change the life of rural people into urban communities. For this reason, it is necessary to socialize environmental sustainability knowledge to young adults so that they are more interested in green business. In line with WWF, conservation behavior and protecting nature in business activities are beneficial for improving human health and quality of life. Both can be aligned with economic growth

Therefore, the study emphasizes the role of green entrepreneurship in understanding sustainable development. The choosing word of green aligns with the green economy which was used in some prior studies such as Lotfi, Yousefi, \& Jafari, (2018); Romanowski \& Gnusowski, (2019); Uslu, Hancıoğlu, \& Demir, (2015). Furthermore, two independent variables are involved in this model. At the individual level, the understanding of triple bottom lines is influenced by ethics or green value so that it is mentioned as a motivator for eco-entrepreneurs (Kirkwood \& Walton, 2010). In a previous study, green value predicted student intentions in sustainable entrepreneurship (Nuringsih, Nuryasman, Prasodjo, \& Amelinda, 2019; Peng, Li, Zhou, \& Sadowski, 2021) and eco-entrepreneurship (Nuringsih \& Puspitowati, 2017). This variable needs to be cultivated among the younger generation so that they respect environmental sustainability and will eventually become interested in green business.

The mechanism for the introduction of sustainable development through education is where McEwen, (2013) stated "entrepreneurship students are an important target group for the expansion of innovation and entrepreneurial activities in the field of sustainability". Other studies such as Abina, Oyeniran, \& Onikosi-Alliyu, (2015); Hafiza Othman \& Othman, (2019); Kaijun \& Ichwatus Sholihah, (2015); Maresch, Harms, Kailer, \& Wimmer-Wurm, (2016); Masri, Abdullah, Asimiran, \& Zaremohzzabieh, (2021); Turker \& Selcuk, (2009); Wang, Yueh, \& Wen, (2019) place entrepreneurial education as one of the factors that influence student interest in entrepreneurship. The education sector has an important role in learning entrepreneurship and understanding sustainable development. This is in line with prior studies of Galindo-Martín, Castaño-Martínez, \& Méndez-Picazo, (2020) where entrepreneurship contributes to the achievement of indicators for sustainable development and SDGs (Apostolopoulos, Al-Dajani, Holt, Jones, \& Newbery, 2018). Therefore, students as representatives of the broad-minded youth are expected to have a mindset about ecofriendly business so that they care about the achievement of SDGs such as "clean water and sanitation, climate action, life below water, and life on land". They must also understand other goals such as "no poverty, zero hunger, good health and well-being, quality education, and gender equality". Lastly, they must master several targets of economic indicators e.g., "decent work and economic growth, industry, innovation, and infrastructure, reduced inequalities, sustainable cities and communities, and responsible consumption and production". These goals need to be introduced through entrepreneurship education.

Under the young adult's perception, this study points to the role of green entrepreneurship in directing the green value and education support toward an understanding of sustainable development. Relevant to the environmental moment, so the terms green and eco-entrepreneurship are used interchangeably in this study. In line with this mechanism, the formulation of the hypothesis is as follows: (1) H1: Green entrepreneurship relates to sustainable development. (2) H2: Green value relates to sustainable development. (3) H3: Education support relates to sustainable development. (4) H4: Green value relates to green entrepreneurship, and (5) H5: Education support related to green entrepreneurship. This model highlights the effect of education support in detecting the involvement of higher education institutions in developing a sustainable regional economy through entrepreneurial empowerment. Threrefore, the goal of the study is to identify the potential for sustainability and test the hypothesis to prove the relationship between the variables in this model. Related to the behavior study, the analysis involved the theory of planned behavior (TPB) for identifying human perception in forming an intention in entrepreneurial activitiy. Furthermore, the benefit of the study is to create suggestions for an education institution and regional government to meet between entrepreneurial education models and regional regulation in aligning with sustainable development. Along with the pandemic, they must be encouraged to be aware of the environment. Although gradually this 
awareness will increase young adults' interest in eco-friendly businesses.

\section{Methodology}

The stages of the research are follow: Firstly determine population and sampling. The population of this research is higher education students who live at Kulon Progo while the respondent selection technique is done by random sampling. As many as 130 students were involved in the study. This group represents young people with the consideration that they have sufficient knowledge about sustainability issues or are more literate about green entrepreneurship and sustainable development than other segments. As young adults are judged to own mindset, lifestyle, or conceptual value related toward green business. This is in line with the curriculum that entrepreneurship is one of the subjects so that respondents have the same opportunity in learning entrepreneurship. In line with the corona outbreak, questionnaires were distributed through google forms to get an overview of respondents' perceptions of sustainability issues.

Secondly, prepare instruments based on indicators in previous research. The study of Kirkwood \& Walton, (2010) as a basis for designing green value instruments, was then developed into three indicators through prior studies (Nuringsih et al., 2019; Nuringsih \& Puspitowati, 2017) with the different research model backgrounds. The education support indicator uses three items from (Turker \& Selcuk, 2009) while the measurement of green entrepreneurship and sustainable development is developed from the instrument in Lotfi et al., (2018). The entire of the indicators are presented to be a questionnaire with scaling 1 (strongly disagree) until 5 (strongly agree). Questionnaires were distributed to respondents in May 2020 and filled out by the respondents themselves. It is easier for respondents to self-administrate their options. Furthermore, the reliability test is used to ensure the accuracy of the instrument concerning composite reliability. By Henseler, Ringle, \& Sarstedt, (2012) the minimum criterion for reliability is 0.70 . In addition, validity testing is carried out on each indicator based on the factor loading criteria above 0.60 or using cross-loading with an indication that the value in one construct must be greater than other constructs.

Thirdly, do the testing and analysis of descriptive and quantitative with Smart PLS software. Some hypotheses were tested in this study so that regression-based analysis was used to determine rejection or acceptance of the hypothesis. Descriptive approach to get a profile of the respondents and the potential for sustainability at Kulon Progo.

Lastly, the results and discussions are identified to formulate implications, limitations, suggestions for the next study and designing regulation of green entrepreneurship and sustainable development. The educational institution must create a mechanism to synchronize the sustainability issues in the education system while the regional government prepares the regulation to support young adults in the learning of the entrepreneurial process.

\section{Results and Discussion}

\subsection{Respondent Profiles and Sustainability Potentials}

The respondent's profile is as follows: $51 \%$ female and $49 \%$ male students. As many as $10 \%$ already have a business, $15 \%$ are starting a business while the rest have not started a business. The majority get a source of funds through seed financings from parents, family, friends, or personal funds (savings). The domicile ratio of respondents was $60 \%$ from inside and $40 \%$ from outside of Kulon Progo. Respondents are currently studying at several universities at Kulon Progo and in the city of Yogyakarta. Spread across various faculties such as economics \& business, engineering, agriculture, law, arts and culture, education science, and others. Even though the study programs differ, respondents can have a good perception of green value and the role of education in the introduction of green entrepreneurship and sustainable development.

Moreover, Kulon Progo is one of the counties in the province of DIY which is located in the middle of Java Island. Currently, most of the Kulon Progo area is located in rural, but in subsequent 
developments in the future, it may rapidly become urban areas. As a part of the DIY province, Kulon Progo can be accessed by the New Yogyakarta International Airport and the southern crossing lane. Both are the economic gateway to the regions in the West and the North of Java. This is a potential for economic growth so that the risk of this progress will impact people's perception of conservation. Thus, it needs a mechanism to anticipate the risk of environmental sustainability. Based on these reasons, the study promotes the green entrepreneurial model to encourage environmental education among students and their value to foster the understanding of sustainable development.

The topographic of Kulon Progo has natural potential as an eco-friendly business. In the northern, it is accessible to the strategic area of Borobudur tourist destinations where it is one of the tens of the new Bali such as "Danau Toba, Tanjung Kelayu, Tanjung Lesung, Bromo, Tengger, Semeru, Mandalika, Labuhan Bajo, and Morotai". Thus the development of the Kulon Progo destination along the Menoreh mountains has an opportunity to support the Borobudur destination. While comparing with the destination in Yogyakarta surroundings, it has potential for the future. The management of tourism objects such as "Kebun Teh Nglinggo, Puncak Suroloyo, Kalibiru, Waduk Sermo", and other destination pioneers is suitable to be developed through the green tourism approach so that the role of green entrepreneurs greatly supports the development of Kulon Progo tourism. The development of tourism areas is certainly related to the hospitality industry and micro, small, and medium enterprises (MSMEs) so that the development of these sectors must be in line with the SDGs. For instance, the leader has created the local product by the brand of "Batik Geblek Renteng" which the creativity of the craftsmen can be developed through eco-friendly products and related to the achievement of SDGs. Creative industries have the potential to support the development of the tourism sector. Thus, traditional arts, traditions, or cultures need to be preserved for their authenticity. This will later become a uniqueness for the people of Kulon Progo. This certainly requires a sense of entrepreneur for ensuring enterprise management in aligning with eco-friendly values.

The agricultural sector is the main commodity for the Kulon Progo people so that the development model needs to be synergized with the sustainability issues through a sustainable agriculture model. Even, in the southern region of Kulon Progo, agricultural commodities have been successfully developed using sandy land, so that local innovation must be supported through green agribusiness. Various potentials can be developed to support sustainable local economic development. The results of this sector are certainly related to food security so that it is an effort to realize a healthy, quality, and sustainable food supply. This performance certainly has a positive impact on health so that green entrepreneurship will be an advantage for this sector.

\subsection{Result of Validity and Reliability Testing}

Table 1 Result of Validity and Reliability Testing

\begin{tabular}{|c|c|c|c|c|c|}
\hline Construct & Indicator & Loading & Status & Reliability & Status \\
\hline \multirow{3}{*}{$\begin{array}{c}\text { Education } \\
\text { Support }\end{array}$} & EDU-1 & 0,906 & Valid & \multirow{3}{*}{0,925} & \multirow{3}{*}{ Reliable } \\
\hline & EDU-2 & 0,862 & Valid & & \\
\hline & EDU-3 & 0,921 & Valid & & \\
\hline \multirow{3}{*}{$\begin{array}{l}\text { Green } \\
\text { Value }\end{array}$} & GV-1 & 0,864 & Valid & \multirow{3}{*}{0,880} & \multirow{3}{*}{ Reliable } \\
\hline & GV-2 & 0,904 & Valid & & \\
\hline & GV-3 & 0,754 & Valid & & \\
\hline \multirow{5}{*}{$\begin{array}{c}\text { Green } \\
\text { Entrepreneurship }\end{array}$} & GEN-1 & 0,757 & Valid & \multirow{5}{*}{0,907} & \multirow{5}{*}{ Reliable } \\
\hline & GEN-2 & 0,805 & Valid & & \\
\hline & GEN-3 & 0,852 & Valid & & \\
\hline & GEN-4 & 0,848 & Valid & & \\
\hline & GEN-5 & 0,803 & Valid & & \\
\hline \multirow{5}{*}{$\begin{array}{l}\text { Sustainable } \\
\text { Development }\end{array}$} & SUSDEV-1 & 0,706 & Valid & \multirow{5}{*}{0,895} & \multirow{5}{*}{ Reliable } \\
\hline & SUSDEV-2 & 0,872 & Valid & & \\
\hline & SUSDEV-3 & 0,813 & Valid & & \\
\hline & SUSDEV-4 & 0,801 & Valid & & \\
\hline & SUSDEV-5 & 0,774 & Valid & & \\
\hline
\end{tabular}

Source: Primary study 
Table 1 shows the results of testing the validity and reliability of the instrument. The value of outer loading is greater than 0.60 so that the status of each indicator is declared valid for measuring each contract. In addition, the composite reliability value is greater than 0.70 so that this value is accurate for measuring green value, education support, green entrepreneurship, and sustainable development. Even so, there is one indicator (SUSDEV-1) that produces the smallest loading value. Thus, the statement regarding "company should give proceeds toward jobs by synergizing economic, social, and environmental factors" tends not to be perceived the same by respondents. However, overall it produces a composite reliability value of 0.895 so the validity and reliability testing criteria have been met for hypothesis testing.

Table 2 The Result Hypothesis Testing

\begin{tabular}{|c|c|c|c|c|c|}
\hline $\begin{array}{c}\text { The Impacts between } \\
\text { variables }\end{array}$ & $\begin{array}{c}\text { Original } \\
\text { Sample }\end{array}$ & $\begin{array}{c}\text { Standard } \\
\text { Error }\end{array}$ & $\begin{array}{c}\mathrm{T} \\
\text { Statistic }\end{array}$ & Hypothesis & Status \\
\hline $\begin{array}{c}\text { Green entrepreneurship } \\
\rightarrow \text { Sustainable development }\end{array}$ & 0,792 & 0,066 & 11,919 & $\mathrm{H} 1$ & Accepted \\
\hline $\begin{array}{c}\text { Green value } \rightarrow \text { Sustainable } \\
\text { development }\end{array}$ & 0,004 & 0,071 & 0,052 & $\mathrm{H} 2$ & Rejected \\
\hline $\begin{array}{c}\text { Education support } \\
\rightarrow \text { Sustainable development }\end{array}$ & 0,076 & 0,087 & 0,874 & $\mathrm{H} 3$ & Rejected \\
\hline $\begin{array}{c}\text { Green value } \rightarrow \text { Green } \\
\text { entrepreneurship }\end{array}$ & 0,500 & 0,118 & 4,241 & $\mathrm{H} 4$ & Accepted \\
\hline $\begin{array}{c}\text { Education support } \rightarrow \text { Green } \\
\text { entrepreneurship }\end{array}$ & 0,273 & 0,107 & 2,557 & $\mathrm{H} 5$ & Accepted \\
\hline \multicolumn{2}{|l|}{$\mathrm{R}^{2}$ Gen: $0.430 ; \mathrm{R}^{2}$ Sus. dev: 0.693} & & \\
\hline
\end{tabular}

Table 2 describes the results of hypothesis testing. Firstly, green entrepreneurship has a significant relationship with sustainable development. It identifies a statistical t-value of 11,919 so that hypothesis $(\mathrm{H} 1)$ is accepted at the level of $1 \%$. Secondly, the $t-v a l u e$ of green value and education support is lower than 1.96 therefore the impact of these variables is not significant toward sustainable development. These prove that $\mathrm{H} 2-\mathrm{H} 3$ was rejected at the level of $5 \%$. Thirdly, the impact of green value toward green entrepreneurship results in the t-value of 4.241 so $\mathrm{H} 4$ is accepted. Meanwhile, the impact of education support toward green entrepreneurship results in a statistical t-value of 2.557 so that $\mathrm{H} 5$ is not rejected at the level of $5 \%$. Both prove that green entrepreneurship can mediate the link between green value and education support to sustainable development.

Table 3 Correlation between Variables

\begin{tabular}{|c|c|c|c|c|}
\hline Construct & EDU & GEN & GV & SUSDEV \\
\hline Education support & 1,000 & - & - & - \\
\hline Green entrepreneurship & 0,467 & 1,000 & - & - \\
\hline Green value & 0,389 & 0,606 & 1,000 & - \\
\hline Sustainable development & 0,447 & 0,830 & 0,513 & 1,000 \\
\hline
\end{tabular}

Based on Table 2 and 3 the contribution of each variable as follows: green value gives the lowest contribution of $0.205 \%$ [calculated from $0.513 * 0.004$ ], education support is $3.397 \%$ [ $0.447 * x 0.076$ ] while green entrepreneurship contributes to sustainable development by $65,736 \%$ [0.830*x0.792] These results indicate that introducing green entrepreneurship forms a mindset towards sustainable development. On the other hand, the green value contributed $30.30 \%[0.606 * 0.500]$ to green entrepreneurship, while education support was $12.75 \%\left[0.467^{*} \times 0.273\right]$. The mark of an asterisk $(*)$ is calculated from the score of correlation shown in Table 3. Generally, it indicates the green entrepreneurship has a role in shaping the mindset of sustainability. An entrepreneurial icon is a moment favored by young people so that by using the current issues about green entrepreneurship it becomes easier to understand sustainability issues for higher education students.

Furthermore, Figure 1 identifies $\mathrm{R}^{2}$ in green entrepreneurship (GEN) of $43 \%(30.30 \%+12.75 \%)$ so as many as $43 \%$ of this construct is influenced by green value (GV) and education support (EDU) while $57 \%$ is influenced by other variables. The $\mathrm{R}^{2}$ value in sustainable development (SUSDEV) is $69.30 \%$ $(0.205 \%+3.397 \%+65.736 \%)$ so that $69.30 \%$ of this construct is influenced by the green value and 
education support while $30.70 \%$ is influenced by other variables outside the model. This shows the mediation of green entrepreneurship so that green value is indirectly taken into account in perceiving sustainable development. The same mechanism also applies to education support, whose impact is taken into account in thinking sustainable development. By the determinant score, it can be ascertained that there are still many factors that influence both. These results capture a perception of young people about environmental sustainability. Although overall this model has not been perfect in proving the relationship between constructs.

Figure 1 The Smart-PIs Result

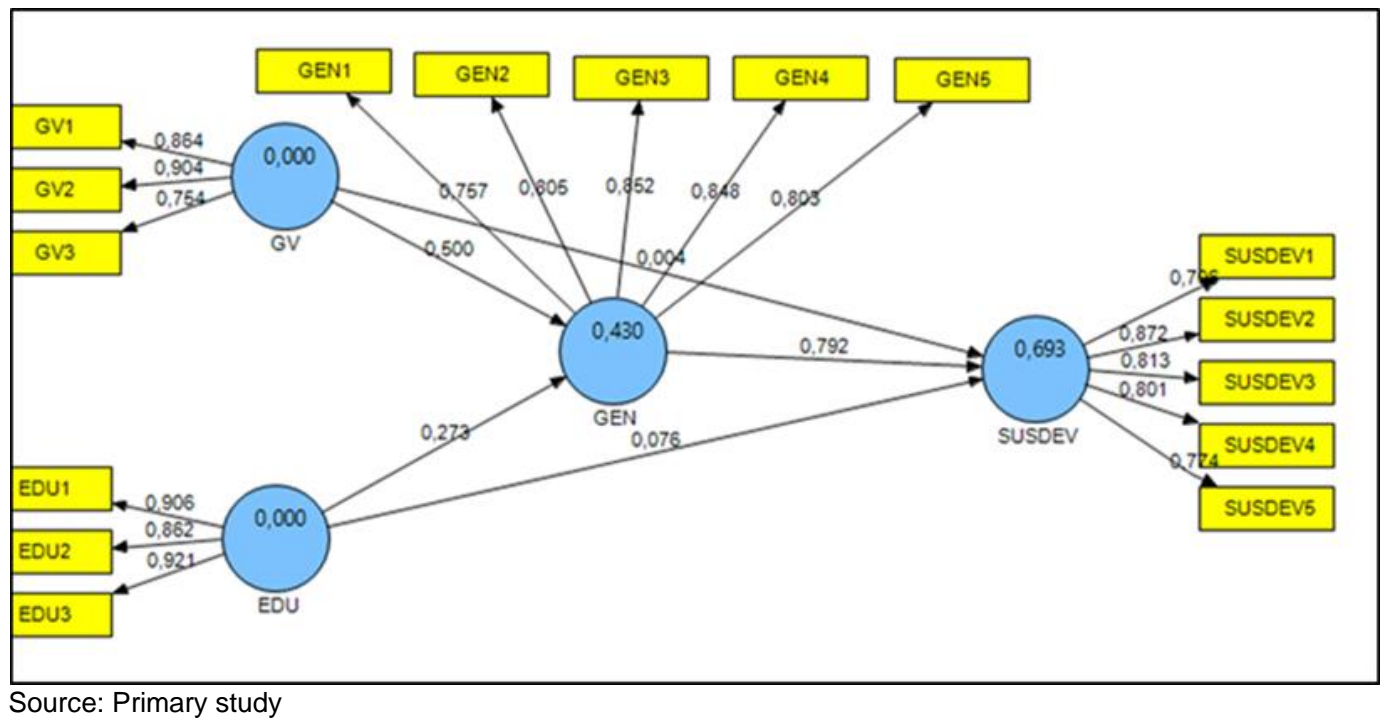

In line with the illustration, these results can capture a picture of the perception of young people about environmental sustainability in the future. Although overall this model has not been perfect in proving the relationship between constructs. To explore how deep the determining factors are in GEN and SUSDEV, so the process will be elaborated in the following discussion section.

\subsection{Discussion}

Based on these results, the discussion is as follow. The study proves the impact of green entrepreneurship. However, along the pandemic of Covid-19, it can touch the conscience of students towards environmental conservation or sustainability. The environmental value must be cultivated from an early age through character education so that as early as possible students understand proenvironmental behavior. When learning is introduced, it will be easy for business instincts to improvise with green business and appreciate SDGs. This can inspire entrepreneurial students to create ecofriendly values in their venture. Moreover, the curriculum of "Merdeka Belajar Kampus Merdeka" or called MBKM is a program formulated by the Ministry of Education and Culture of the Republic of Indonesia which is planned to start in 2021. The mechanism of this program is that students can learn not only by studying their study program but can study in the same university or study programs at different universities. It is a breakthrough in higher education student learning, including through entrepreneurship and business innovation. Relevant to this icon, entrepreneurship education does not only emphasize taking profit but needs to be synchronized with the triple bottom line.

Generally, aligning with entrepreneurial education so many innovations can be created in lining with sustainability. For instance, making eco-friendly innovations like The Body Shop projects (Ganatra et al., 2021) that concern sustainability by producing various products from green materials. In fact, it has the five core values such as "against animal testing, support community trade, activated self-esteem, defend human rights, and protect our planet" that strengthen this brand as a sustainable corporation. Further, related to the agriculture community, so in ensuring environmental performance can be driven from the green supply chain (Endyanti, Kusmantini, \& Wahyuningsih, 2021). It helps farmers in maintaining agricultural ecosystems in rural areas. In the same case, Alrubah et al., (2020) noted "IKEA 
emphasis on sustainability and environmental design that make sure provide better everyday life for the many people". The sense of sustainability seems on the willingness to help others through CRS programs during pandemics (Handayati, Wafaretta, Anugrahani, \& Fauzan, 2021). Discussion with students will increase their insight into sustainability so that indirectly contribute to "entrepreneurial personality" (Wikantiyoso, Riyanti, \& Suryani, 2021). It depicts that the business innovation must be introduced for students so they will get insight that aligns with the sustainability values. The educational institution support is required to equate entrepreneurial perceptions with the SDGs.

It was initiated by the United Nations as a continuation of the Millennium Development Goals (MDGs) which ended in 2015. As the second 15 year program (2016-2030), the SDGs have 17 goals to realize the welfare of the global community. These targets are divided into social, economic, and environmental aspects, so the term triple bottom line (TBL) was coined by Elkington. The overall target must be achieved by the end of 2030 so that in the pursuit of achievement, it requires the participation of various parties such as entrepreneurs, communities, educational institutions, regional governments, and NGOs. Economic opportunities are abundant in this region so that in alignment with the challenges of global community development, a collaboration between stakeholders is needed.

Green entrepreneurship pursues environmental and economic gain including individual economic improvement, job creation, increased public purchasing power, capturing local market potential, utilizing local resources, and ultimately encouraging local economic growth. At the same time, environmental orientation support behavior towards environmental conservation, water awareness, waste reduction, and recycling. This consciousness will foster environmental and social responsibility, thereby contributing to local economic growth. This approach has been implemented through "BelaBeli Kulon Progo" which can realize some best practices based on the TBL and double bottom line (Nuringsih \& Nuryasman, 2020). Further appreciation is needed to maintain this performance for ensuring the welfare of future generations.

The mechanism follows from Lotfi et al., (2018) that when managers implement eco-friendly business, it means that they also implement important aspects of SDGs in business activities. The results are also in line with the idea of Galindo-Martín et al., (2020) and Apostolopoulos et al., (2018) that entrepreneurship is a means to encourage the achievement of the SDGs. Some of the triple bottom line goals can be realized through entrepreneurial activities. The positive influence of green value on green entrepreneurship is a motivational effect for entrepreneurs so that they are interested in maintaining a green business (Kirkwood \& Walton, 2010). Regarding student respondents, their perceptions indicate an interest in an environmental sustainability-oriented business (Nuringsih et al., 2019). In general, the results show that educational support has a significant effect on entrepreneurship so that it aligns with some previous studies e.g.,(Hafiza Othman \& Othman, 2019; Kaijun \& Ichwatus Sholihah, 2015; Maresch et al., 2016; Turker \& Selcuk, 2009). The development of social media enriches the knowledge base of students so that environmental sustainability and entrepreneurial insights are understood simultaneously. Although not directly impact, a pandemic situation forms a mindset towards sustainability or provides some insights about green entrepreneurial activity.

However, the two paths are not matched with the previous estimates so both have not directly formed an understanding of sustainable development. This is a limitation of the research, but this model can provide students with a mindset on sustainability issues. Related to the determinant score, it shows that many factors need to be considered in encouraging green entrepreneurship. This can be explained through the Entrepreneurial Support Model (ESM) from Turker \& Selcuk, (2009). This model is still relevant in explaining efforts to form student interest in entrepreneurship. ESM consists of government support, university support, and relation support so that the synergy of stakeholders supports the formation of interest in entrepreneurship. The next mechanism relates to the psychological aspects where through TPB (Ajzen, 1991; Nishimura \& Tristan, 2011) the intention is formed by attitude, social norms, and perceived behavior control in a person so that feel confident in entrepreneurship and are finally interested in creating a startup. In aligning with TPB, the perceived green value and role of education support encourage the attitude toward green entrepreneurship, 
then forces the social pressure on sustainability. Lastly, the continual process will form self-efficacy to start an eco-friendly business in the future. If they are reconciled with ESM, social norms are important in forming intentions, especially those related to sustainability aspects which are relatively new to the society. The existence of supporting factors in ESM as a form of social norms is needed to encourage business actors' interest in business sustainability. This is evidenced in previous studies e.g., (Koe, Omar, \& Majid, 2014; Koe, Omar, \& Sa'ari, 2015; Koe \& Majid, 2014; Majid, Latif, \& Koe, 2017; Nuringsih \& Nuryasman, 2020; Sargani et al., 2020).

Furthermore, in determining sustainable development, it is deemed necessary to consider other variables through local wisdom or local genius that exist in people's lives. Millennials do not realize that ancestral traditions provide values or moral messages that are relevant to the meaning of sustainability in the recent era. There is one term in Javanese including Kulon Progo's people that used to be often spoken by the community, namely "Lumintu or Lumintri". This term has the meaning of being sustainable so that the philosophy of sustainability is not something new to people in regions. Thus, forms of local wisdom must be preserved as part of the steps to maintain traditions or cultures that are in harmony with sustainability aspects.

Lastly, it introduces a model involving four partners in developing green entrepreneurship prototype, namely (1) regional government provides legal and regulatory support to green entrepreneurs, (2) educational institution supports knowledge transfer and education activities for entrepreneurs, newcomers, and students as nascent entrepreneurs. Education is also given to the community or potential customer to provide socialization about pro-environmental behavior and responsible production \& consumption, (3) the financial institution facilitates through low-cost credit access for the new ventures, and (4) corporate through the corporate social responsibility programs bring innovation, technology, and market access to ultimately increase sales growth. Eventually, this collaboration can complete the achievement of other goals such as poverty alleviation, reducing hunger, improving the quality of education, health quality, providing clean water, and others. For ensuring the implementation, the collaboration can be improved with other parties. These dimensions consist of economy, social, ecology, and local wisdom or called as four bottom lines (FBL) so that the balance that exists in these four pillars is expected to be able to improve the well-being and quality of life of the community, so finally will participate in realizing the SDGs until 2030.

However, not all business owners or nascent entrepreneurs have the same readiness to adopt a green business model. The implementation process can be carried out in stages. Based on a study by Belz \& Binder, (2017), a convergent process model was introduced as a stage towards sustainable entrepreneurship. In this case, starting a business with two dimensions or called as double bottom line (DBL), for example (1) economy and local wisdom/culture, (2) economy and society, and (3) economy and ecology. Furthermore, after making it possible it can be done by considering the TBL, such as economic, social, and cultural. Thus covering economic, social, and ecology. For large-scale businesses can adopt these four dimensions in building a green business. Overall, these stages consist of DBL, TBL, and $\mathrm{FBL}$ tends to make it easier for entrepreneurs to transform in the concept of sustainability.

\section{Conclusion}

The results identify the potential for business development orientation to environmental sustainability including agricultural, tourism, MSMEs, creative industry, and hospitality at Kulon Progo. In addition, hypothesis testing proves the role of green entrepreneurship in mediating the relationship between green value and education support for sustainable development. Even so, the constructs of green value and education support have not shown their effect on sustainable development. Entrepreneurship learning must synergize with the achievement targets of SDGs so that young adults understand the importance of environmental sustainability in entrepreneurial activities and adopt some goals of sustainability. Through entrepreneurship learning, it forms attitudes and self-efficacy towards green entrepreneurship. Finally, the study designs the involvement of stakeholders to educate, assist, facilitate, and motivate people who have an interest in green business. It is the four 
pillars of the green entrepreneurship model by emphasizing the balance of four dimensions, namely economic, social, local wisdom, and ecology. The adoption process was not carried out spontaneously but was carried out in stages starting from the double bottom line until the four bottom lines.

The limitation is that the two paths of analysis are not significant. However, the results provide an overview of students' perceptions of both issues. Suggestion for the next study is to consider several independent variables, for instance: (1) regional government support as one of the attributes in ESM, (2) local wisdom values to understand traditions or positive values that have been maintained until now, and (3) green entrepreneurial orientation to understand respondents' perceptions of innovation, risk-taking and being proactive with the sustainability issues. These constructs are used to predict young adults' perceptions of green entrepreneurship and finally giving impact to the SDGs.

\section{References}

1. Abina, M. ., Oyeniran, I. ., \& Onikosi-Alliyu, S. (2015). Determinants of Eco Entrepreneurial Intention among Students: A Case Study of University Students in Ilorin and Malete. Ethiopian Journal of Environmental Studies and Management, 8(1), 107-112. https://doi.org/10.4314/ejesm.v8i1.10

2. Ajzen, I. (1991). The Theory of Planned Behavior. Organizational Behavior and Human Decision Processes, 50(2), 179-211. https://doi.org/10.1016/0749-5978(91)90020-T

3. Alrubah, S. A., Alsubaie, L. K., Quttainah, M. A., Pal, M., Pandey, R., Shamiliy, T. A., \& Aishan, N. (2020). Factors Affecting Environmental Performance: A Study of IKEA. International Journal of Tourism and Hospitality in Asia Pasific, 3(3), 79-89. https://doi.org/10.32535/ijthap.v3i3.949

4. Apostolopoulos, N., Al-Dajani, H., Holt, D., Jones, P., \& Newbery, R. (2018). Entrepreneurship and the Sustainable Development Goals. In Contemporary Issues in Entrepreneurship Research (pp. 17). https://doi.org/10.1108/S2040-724620160000006017

5. Belz, F. M., \& Binder, J. K. (2017). Sustainable Entrepreneurship: A Convergent Process Model. Business Strategy and the Environment, 26(1), 1-17. https://doi.org/10.1002/bse.1887

6. Endyanti, S. A., Kusmantini, T., \& Wahyuningsih, T. (2021). The Analysis of the Influence of Green Supply Chain Management and Low-Cost Strategies on Environmental Performance. International Journal of Applied Business and International Management, 6(1), 40-48. https://doi.org/10.32535/ijabim.v6i1.959

7. Galindo-Martín, M.-A., Castaño-Martínez, M.-S., \& Méndez-Picazo, M.-T. (2020). The Relationship between Green Innovation, Social Entrepreneurship, and Sustainable Development. Sustainability, 12(11), 4467-4486. https://doi.org/10.3390/su12114467

8. Ganatra, V., Sinha, R., Srishti, Pandey, R., Kadam, P., Ristiansyah, S. A., \& Wei, L. P. (2021). The Body Shop "Forever Against Animal Testing." International Journal of Applied Business and International Management (IJABIM), 6(1), 90-100. Retrieved from https://ejournal.aibpm.org/index.php/IJABIM/article/view/1082/980

9. Hafiza Othman, N., \& Othman, N. (2019). A Systematic Review on Entrepreneurship Education in Higher Learning Institutions in Southeast Asia. Universal Journal of Educational Research, 7(11), 2406-2416. https://doi.org/10.13189/ujer.2019.071118

10. Handayati, P., Wafaretta, V., Anugrahani, I. S., \& Fauzan, S. (2021). CSR Practices in Food and Beverage Companies During Pandemic. Asia Pacific Journal of Management and Education, 4(1), 917. https://doi.org/10.32535/apjme.v4i1.1046

11.Henseler, J., Ringle, C. M., \& Sarstedt, M. (2012). Using Partial Least Squares Path Modeling in Advertising Research: Basic Concepts and Recent Issues. In S. Okazaki (Ed.), Handbook of Research on International Advertising (pp. 252-276). Edward Elgar Publishing. https://doi.org/10.4337/9781781001042.00023

12.Kaijun, Y., \& Ichwatus Sholihah, P. (2015). A Comparative Study of the Indonesia and Chinese Educative Systems Concerning the Dominant Incentives to Entrepreneurial Spirit (Desire for a New 
Venturing) of Business School Students. Journal of Innovation and Entrepreneurship, 4(1), 1-16. https://doi.org/10.1186/s13731-014-0014-0

13.Kirkwood, J., \& Walton, S. (2010). What Motivates Ecopreneurs to Start Businesses? International Journal of Entrepreneurial Behavior \& Research, 16(3), 204-228.

https://doi.org/10.1108/13552551011042799

14.Koe, W.-L., Omar, R., \& Majid, I. A. (2014). Factors Associated with Propensity for Sustainable Entrepreneurship. Procedia - Social and Behavioral Sciences, 130, 65-74. https://doi.org/10.1016/j.sbspro.2014.04.009

15.Koe, W.-L., Omar, R., \& Sa'ari, J. R. (2015). Factors Influencing Propensity to Sustainable Entrepreneurship of SMEs in Malaysia. Procedia - Social and Behavioral Sciences, 172, 570-577. https://doi.org/10.1016/j.sbspro.2015.01.404

16.Koe, W., \& Majid, I. A. (2014). Socio-Cultural Factors and Intention towards Sustainable Entrepreneurship. Eurasian Journal of Business and Economics, 7(13), 145-156. Retrieved from https://www.ejbe.org/EJBE2014Vol07No13p145KOE-MAJID.pdf

17.Lotfi, M., Yousefi, A., \& Jafari, S. (2018). The Effect of Emerging Green Market on Green Entrepreneurship and Sustainable Development in Knowledge-Based Companies. Sustainability, 10(7), 2308-2226. https://doi.org/10.3390/su10072308

18.Majid, I. A., Latif, A., \& Koe, W.-L. (2017). SMEs' Intention towards Sustainable Entrepreneurship. European Journal of Multidisciplinary Studies, 2(3), 24-32. https://doi.org/10.26417/ejms.v4i3.p24-32

19.Maresch, D., Harms, R., Kailer, N., \& Wimmer-Wurm, B. (2016). The Impact of Entrepreneurship Education on the Entrepreneurial Intention of Students in Science and Engineering versus Business Studies University Programs. Technological Forecasting and Social Change, 104, 172-179. https://doi.org/10.1016/j.techfore.2015.11.006

20.Masri, N., Abdullah, A., Asimiran, S., \& Zaremohzzabieh, Z. (2021). Relationship between Engagement in Learning Entrepreneurship Education and Entrepreneurial Intention among Vocational College Students. Pertanika Journal of Science and Technology, 29(S1), 19-38. https://doi.org/10.47836/pjssh.29.s1.02

21.McEwen, T. (2013). Ecopreneurship as a Solution to Environmental Problems: Implications for College Level Entrepreneurship Education. International Journal of Academic Research in Business and Social Sciences, 3(5), 264-288. Retrieved from https://silo.tips/download/ecopreneurship-asa-solution-to-environmental-problems-implications-for-college

22.Nishimura, J. S., \& Tristan, O. M. (2011). Using the Theory of Planned Behavior to Predict Nascent Entrepreneurship. Academia, Revista Latinoamericana de Administracion, 46, 55-71. Retrieved from https://www.redalyc.org/pdf/716/71617238005.pdf

23.Nuringsih, K., \& Nuryasman, MN. (2020). Propensity for Sustainable Entrepreneurship of MSEs Owner in Yogyakarta, Indonesia. In Urban Development and Lifestyle. Nova, Social Sciences, Urban Development and Infrastructure, Urban Studies.

24.Nuringsih, K., Nuryasman, MN., Prasodjo, I., \& Amelinda, R. (2019). Sustainable Entrepreneurial Intention: The Perceived of Triple Bottom Line among Female Students. Jurnal Manajemen, 23(2), 168-190. https://doi.org/10.24912/jm.v23i2.472

25.Nuringsih, K., \& Puspitowati, I. (2017). Determinants of Eco Entrepreneurial Intention Among Students: Study in the Entrepreneurial Education Practices. Advanced Science Letters, 23(8), 72817284. https://doi.org/10.1166/asl.2017.9351

26.Peng, H., Li, B., Zhou, C., \& Sadowski, B. M. (2021). How Does the Appeal of Environmental Values Influence Sustainable Entrepreneurial Intention? International Journal of Environmental Research and Public Health, 18(3), 1070-1095. https://doi.org/10.3390/ijerph18031070

27.Romanowski, R., \& Gnusowski, M. (2019). Green Entrepreneurship in The Quintaple Helix Model. 
In R. Romanowski (Ed.), Managing Economic Innovations - Ideas and Institutions (pp. 103-118). Bogucki Wydawnictwo Naukowe. https://doi.org/10.12657/9788379862764-7

28.Sargani, G. R., Zhou, D., Raza, M. H., \& Wei, Y. (2020). Sustainable Entrepreneurship in the Agriculture Sector: The Nexus of the Triple Bottom Line Measurement Approach. Sustainability, 12(8), 3275-3300. https://doi.org/10.3390/su12083275

29.Turker, D., \& Sonmez Selcuk, S. (2009). Which Factors Affect Entrepreneurial Intention of University Students? Journal of European Industrial Training, 33(2), 142-159.

https://doi.org/10.1108/03090590910939049

30.UNEP. (2011). Towards a Green Economy Pathways to Sustainable Development and Poverty Eradiction: A Synthesis for Policy Makers. (A. Steiner, Ed.), United Nations Environment Programme (UNEP). Retrieved from www.unep.org/greeneconomy

31.Uslu, Y. D., Hancıoğlu, Y., \& Demir, E. (2015). Applicability to Green Entrepreneurship in Turkey: A Situation Analysis. Procedia - Social and Behavioral Sciences, 195, 1238-1245. https://doi.org/10.1016/j.sbspro.2015.06.266

32.Wang, S.-M., Yueh, H.-P., \& Wen, P.-C. (2019). How the New Type of Entrepreneurship Education Complements the Traditional One in Developing Entrepreneurial Competencies and Intention. Frontiers in Psychology, 10, 1-12. https://doi.org/10.3389/fpsyg.2019.02048

33.Wikantiyoso, B., Riyanti, B. P. D., \& Suryani, A. O. (2021). A Construction of Entrepreneurial Personality Tests: Testing Archetype Personality Inventory in Entrepreneurship. International Journal of Applied Business and International Management, 6(1), 1-13.

https://doi.org/10.32535/ijabim.v6i1.1085

34.WWF International. (2020). Theloss of Nature and Rise of Pandemics - Protecting Human and Planetary Health. WWW.Panda.Org. Retrieved from

https://wwfint.awsassets.panda.org/downloads/the_loss_of_nature_and_rise_of_pandemics protecting_human_and_planetary_health.pdf 